\title{
Reversible Inactivation of the Bed Nucleus of the Stria Terminalis Prevents Reinstatement But Not Renewal of Extinguished Fear ${ }^{1,2,3}$
}

\author{
(D)Travis D. Goode, Janice J. Kim, and ${ }^{\circledR}$ Stephen Maren
}

DOI:http://dx.doi.org/10.1523/ENEURO.0037-15.2015

Institute for Neuroscience and Department of Psychology, Texas A\&M University, College Station, Texas 77843

\begin{abstract}
The extinction of conditioned fear is labile. For example, fear to an extinguished conditioned stimulus (CS) returns after presentation of an aversive stimulus ("reinstatement") or a change in context ("renewal"). Substantial research implicates the bed nucleus of the stria terminalis (BNST) in the stress-induced relapse of extinguished behaviors, such as in instrumental drug seeking, but its role in the relapse of extinguished fear responses is not clear. Here, we explored the role of the BNST in both the reinstatement and renewal of fear, two forms of relapse that are differentially triggered by stress. In Experiment 1, rats received pairings of an auditory CS and footshock unconditioned stimulus (US) followed by an extinction procedure. After extinction, rats received an unsignaled US to reinstate fear to the extinguished CS. Twenty-four hours later, they were infused with either muscimol or vehicle into the BNST immediately prior to a CS retrieval test. In Experiment 2, rats were conditioned and extinguished in two distinct contexts. Twenty-four hours after extinction, the rats were infused with muscimol, NBQX, or vehicle immediately prior to a CS retrieval test in either the extinction context or a different (but familiar) context. In both experiments, freezing behavior served as the index of conditioned fear. The results revealed that BNST inactivation prevented reinstatement (Experiment 1), but not renewal (Experiment 2), of conditioned freezing to the extinguished CS. Hence, the BNST is critical for the reinstatement of extinguished fear in an aversive context, but not for the contextual retrieval processes that mediate fear renewal.
\end{abstract}

Key words: BNST; extinction; fear; muscimol; reinstatement; renewal

\section{Significance Statement}

Relapse of extinguished fear is a major challenge to clinical treatments of fear-related anxiety disorders (e.g., exposure therapy). Pavlovian fear conditioning and extinction are important models for understanding the behavioral and brain mechanisms underlying fear relapse. Here we explore the role of the bed nucleus of the stria terminalis (BNST) in two different forms of fear relapse in rats: "reinstatement" and "renewal." We find that reversible inactivation of the BNST prevents the reinstatement, but not the renewal, of extinguished fear. This reveals a dissociation in the role of the BNST in different forms of relapse, a finding that will serve to enhance the selectivity of neural interventions for anxiety disorders.

\section{Introduction}

Fear relapse plagues clinical interventions for fearrelated anxiety disorders (Hooley, 2007; Boschen et al.,
2009; Vervliet et al., 2013b). Various factors-such as the nature of the therapeutic intervention, duration of time since treatment, and intervening stress-have been

\footnotetext{
${ }^{1}$ The authors declare no competing financial interests.

${ }^{2}$ T.D.G., J.J.K., and S.M. designed research; T.D.G. and J.J.K. performed research; T.D.G., J.J.K., and S.M. analyzed data; T.D.G., J.J.K., and S.M. wrote the paper.
} 
shown to be important in determining the degree of retention of extinguished fear in humans and other animals (Kehoe and Macrae, 1997; Bouton, 2002, 2014; Myers and Davis, 2002; Bouton et al., 2006; Hermans et al., 2006; Fitzgerald et al., 2014; Goode and Maren, 2014; Luck and Lipp, 2015). Pavlovian fear conditioning and extinction in rodents provides a clinically relevant model to explore the behavioral and brain mechanisms of relapse. Specifically, fear conditioning in rats is a behavioral procedure through which subjects experience concomitant pairings of a neutral conditioned stimulus (CS), such as a tone, with an aversive unconditioned stimulus (US), such as a footshock (Rescorla, 1988a,b). After fear conditioning, presentation of the CS alone comes to elicit conditioned fear responses (CRs), including freezing behavior (Fendt and Fanselow, 1999; LeDoux, 2000; Maren, 2001). Fear CRs also occur in the place or "context" in which fear conditioning was experienced (Bouton and King, 1983; Maren et al., 2013).

After conditioning, repeated presentations of the CS in the absence of footshock lead to the extinction of fear (Pavlov, 1927; Chang et al., 2009). It is widely believed that research on fear extinction in rodents can enhance our understanding of exposure therapy in humans (Barad, 2005; Milad et al., 2006, 2014; Morrison and Ressler, 2014). Extensive research indicates that extinction training does not necessarily erase fear memory; rather, it results in a new "inhibitory" memory that limits the expression of the fear (Konorski, 1967; Bouton, 2004; Maren, 2011). Consequently, extinction memories are susceptible to relapse. Two forms of fear relapse have received considerable attention over the years: "reinstatement" and "renewal." Reinstatement of fear occurs when an aversive, unsignaled US is experienced prior to presentation of the extinguished CS (Rescorla and Heth, 1975; Bouton and Bolles, 1979). Reinstatement is most robust in contexts in which reinstating shocks are delivered, although it can also occur in contexts never paired with shock (Westbrook et al., 2002; see also Morris et al., 2005a; Halladay et al., 2012; Goode et al., 2015). This suggests that reinstatement can be mediated by either direct context-US associations (Bouton and King, 1983; Bouton et al., 2006) or though stress states that generalize across contexts (Haroutunian and Riccio, 1977; Morris et al., 2005b; Deschaux et al., 2013). Fear renewal, on the other hand, occurs when a CS is presented outside of its extinction context (Bouton and Bolles, 1979; Polack et al., 2013; Vervliet et al., 2013a). Importantly, renewal does not require that the animal experience the US after extinction. Indeed, direct context-US associations do not mediate

${ }^{3}$ This work was funded by Grant R01MH065961 from the National Institutes of Health to S.M.

Correspondence should be addressed to: Stephen Maren, Institute for Neuroscience and Department of Psychology, Texas A\&M University, College Station, TX 77843. E-mail: maren@tamu.edu.

DOI:http://dx.doi.org/10.1523/ENEURO.0037-15.2015

Copyright (C) 2015 Goode et al.

This is an open-access article distributed under the terms of the Creative Commons Attribution 4.0 International, which permits unrestricted use, distribution and reproduction in any medium provided that the original work is properly attributed. renewal (Bouton and Ricker, 1994; Harris et al., 2000; Corcoran and Maren, 2004).

The different roles that context plays in reinstatement and renewal suggest that distinct neural circuits mediate them. One brain area that has been implicated in reinstatement is the bed nucleus of the stria terminalis (BNST). In particular, BNST lesions impair the shockinduced reinstatement of fear (Waddell et al., 2006; see also Waddell et al., 2008). Sustained fear responses to conditioned contexts (Sullivan et al., 2004) and longduration CSs (Waddell et al., 2006) also appear to rely on the BNST (also, see Walker and Davis, 1997). Conversely, BNST manipulations do not affect fear to short-duration CSs paired with shock (LeDoux et al., 1988; Sullivan et al., 2004; Waddell et al., 2006; Zimmerman and Maren, 2011). Coinciding with this evidence, BNST circuitry is also involved in the stress-induced reinstatement of drug seeking. For example, antagonism of corticotropin-releasing factor receptors within the BNST blocks the reinstatement of cocaine seeking after footshock exposure (Erb and Stewart, 1999). Similarly, pharmacological inactivation of the BNST prevents the stress-induced reinstatement of cocaine seeking following systemic administration of the anxiogenic drug yohimbine (Buffalari and See, 2011). Collectively, these data suggest that the BNST may have a selective role in forms of relapse that depend on stress and/or contextual fear, such as in reinstatement. To explore this question, we examined the consequences of reversibly inactivating the BNST in the expression of both the reinstatement and renewal of fear after extinction in rats. We hypothesized that BNST inactivation would attenuate the reinstatement, but not the renewal, of extinguished fear.

\section{Materials and Methods}

\section{Subjects}

All subjects were adult (200-250 g) male Long-Evans (Blue Spruce) rats from Harlan Laboratories. Upon arrival, rats were individually housed in clear plastic cages on a rotating cage rack (Animal Care Systems). Group assignments for behavioral training were randomized for cage position on the racks. Rats were given free access to standard rodent chow and water. Sawdust served as bedding for the rats (bedding was changed once a week). Behavioral experiments took place on different days from the days that cages were changed. Rats were kept on a fixed light/dark cycle, with rats experiencing $14 \mathrm{~h}$ of light (starting at 7:00 A.M.) followed by $10 \mathrm{~h}$ of darkness each day. All handling, surgeries, and behavioral testing occurred during the light hours of the light/dark cycle. The experimenters handled each rat for $1 \mathrm{~min} / \mathrm{d}$ for $5 \mathrm{~d}$ prior to the start of surgeries. Additionally, rats were habituated to the infusion procedures and to the infusion room prior to behavioral training. The Texas A\&M University Institutional Animal Care and Use Committee approved all experimental procedures.

\section{Surgery}

Rats were anesthetized with an intraperitoneal injection of ketamine $(100 \mathrm{mg} / \mathrm{kg})$ and xylazine $(10 \mathrm{mg} / \mathrm{kg})$, and 
were treated with atropine methyl nitrate $(0.4 \mathrm{mg} / \mathrm{kg}$, i.p.). After the induction of anesthesia, the head of each rat was shaved, and the rats were placed in a stereotaxic frame (David Kopf Instruments). The scalp was incised, and the skull was leveled, with bregma and lambda in the same horizontal plane. Small holes were drilled in the skull and steel guide cannulae (26 gauge, $8 \mathrm{~mm}$; Small Parts) were lowered into the BNST ( $0 \mathrm{~mm}$ anteroposterior to bregma, $\pm 2.7 \mathrm{~mm}$ mediolateral, and $-5.9 \mathrm{~mm}$ ventral to dura). Guide cannulae were angled at $10^{\circ}$ to limit penetration of the lateral ventricles. Three stainless steel screws were affixed to the skull, and the entire skull surface was covered with dental cement to secure the cannulae to the skull. Stainless steel obturators (30 gauge, $9 \mathrm{~mm}$; Small Parts) were placed inside each cannula and changed every $2 \mathrm{~d}$ prior to behavioral testing. Rats were given a single bacon-flavored Rimadyl tablet $(2 \mathrm{mg} / \mathrm{tablet}$; BioServ) following surgery. The rats were allowed at least 1 week to recover from surgery before behavioral testing.

\section{Behavioral apparatus}

Behavioral testing was conducted in two distinct rooms within the laboratory ("Wellborn" and "University"). Each testing room contained eight identical conditioning chambers (Med Associates) fabricated with aluminum (sidewalls) and Plexiglas (rear wall, ceiling, and front cage door) walls $(30 \times 24 \times 21 \mathrm{~cm})$. The conditioning chambers were housed in external sound-attenuating cabinets. The floor of each chamber consisted of 19 stainless steel rods (4 $\mathrm{mm}$ in diameter); each rod was spaced $1.5 \mathrm{~cm}$ apart (center to center). Each chamber was equipped with a speaker to provide the CS. As described for each context (see below), a $15 \mathrm{~W}$ house light provided ambient lighting and a cabinet fan provided background noise for each chamber ( $\sim 70 \mathrm{~dB})$. The grid floors of each chamber were connected to a shock source and a solid-state grid scrambler to deliver the footshock US (Med Associates). Each chamber rested on a load-cell platform that detected chamber displacement in response to the movement of each animal. Load-cell activity values (range, -10 to $+10 \mathrm{~V}$ ) were acquired during all behavioral phases and digitized at $5 \mathrm{~Hz}$ with Threshold Activity Software (Med Associates). Load-cell output was transformed off-line to values ranging from 0 to 100 (higher values indicate more displacement of the cage). A bout of freezing was scored if the absolute values of load-cell activity were $\leq 10$ for $\geq 1$ $s$ (Maren, 1998). The number of $1 \mathrm{~s}$ bins of freezing was divided by the total number of bins in each observation period (typically, a $30 \mathrm{~s}$ or $1 \mathrm{~min}$ period after each trial) to yield the percentage of time each animal was freezing.

Distinct contexts were created through the use of different odors and visual cues. For Experiment 1, conditioning and extinction occurred in Context $A$; these chambers were located in the Wellborn test room in the laboratory. For Context A, the cage walls were wiped with acetic acid $(1.5 \%)$ and a small volume was placed in the trays underneath the grid floor. The houselights were extinguished, but the overhead fluorescent room lights were illuminated. Rats were transported to Context $A$ in white containers, and the cabinet doors enclosing the conditioning cham- bers were open during testing. The reinstatement sessions occurred in Context B; these chambers were located in the University test room in the laboratory. For Context B, ammonium hydroxide (1\%) was used to wipe the cage walls and a small volume was placed in the trays underneath the grid floors. The overhead fluorescent room lights remained off (red room lights provided overhead illumination); the houselights within each testing chamber were illuminated. Rats were transported to Context B in black containers, and the cabinet doors enclosing the conditioning chambers were closed during testing. Cabinet fans were turned on for both Context $A$ and $B$ in Experiment 1. For Experiment 2, conditioning was conducted in Context A as described above, whereas extinction and renewal testing used Contexts $B$ and $C$ (per group assignments; cabinet fans were turned off for Contexts $B$ and $C$ in Experiment 2). For Context $C$ (Wellborn room), ethanol (70\%) was used to wipe the cage walls and a small volume was placed in the trays beneath the grid floor. The houselights were illuminated, and the overhead lights were extinguished; a thin black Plexiglas sheet covered the grid floor for Context C. Cabinet doors enclosing the chambers were open during testing in Context C. Rats were transported to Context $\mathrm{C}$ in white 5 gallon buckets; a layer of sawdust was placed in each bucket and changed out for each squad of animals.

\section{Behavioral procedures}

Experiment 1: effects of BNST inactivation on the expression of reinstatement

An illustration of the behavioral paradigm for Experiment 1 is shown in Figure 1. Prior to behavioral testing, 32 rats were randomly assigned to groups that would receive intracranial infusions of either muscimol (MUS; a selective $\mathrm{GABA}_{\mathrm{A}}$ receptor agonist; $n=16$ ) or vehicle (VEH; physiological saline; $n=16)$ prior to retrieval testing. MUS rats received a total of $0.3 \mu \mathrm{g}$ of muscimol $(1.0 \mu \mathrm{g} / \mu \mathrm{l}$ in $0.3 \mu \mathrm{l})$ per hemisphere. VEH rats were infused with $0.3 \mu \mathrm{l}$ of physiological saline per hemisphere. All infusions occurred over $1 \mathrm{~min}$ at a rate of $0.3 \mu \mathrm{l} / \mathrm{min}$. Within each drug condition, rats were also randomly assigned to receive reinstatement shock in either the test context (Context $B$ ) or the extinction context (Context A). Rats did not differ at test based on the context in which the reinstatement shock was delivered $(F$ values $<1)$; therefore, we collapsed rats across this condition.

On Day 1, rats were transported to Context $A$ for fear conditioning. Three minutes after placement in the chambers, rats received five auditory CSs $(10 \mathrm{~s}, 2 \mathrm{kHz}, 80$ $\mathrm{dB}$ )-footshock US (2 s, $1 \mathrm{~mA}$ ) pairings [US onset occurred upon CS offset; $70 \mathrm{~s}$ intertrial intervals (ITIs)]. After the final conditioning trial, rats remained in the chambers for $1 \mathrm{~min}$ before being returned to their home cages. Twenty-four hours later, rats underwent the first of two extinction sessions. During these sessions, they were returned to the conditioning context (Context A), and, after $3 \mathrm{~min}$, rats were presented with $45 \mathrm{CS}$-alone trials (40 s ITIs). After the final CS presentation, the rats remained in the chambers for $3 \mathrm{~min}$ before being returned to their home cages. The second extinction session was identical to the first and occurred on the following day. Twenty-four hours 


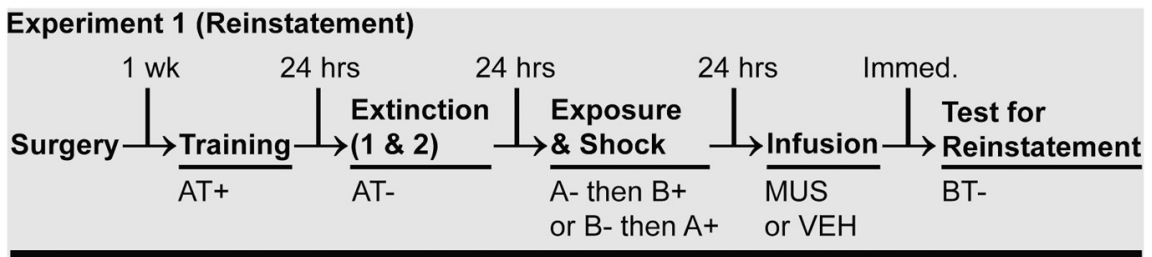

Experiment 2 (Renewal)

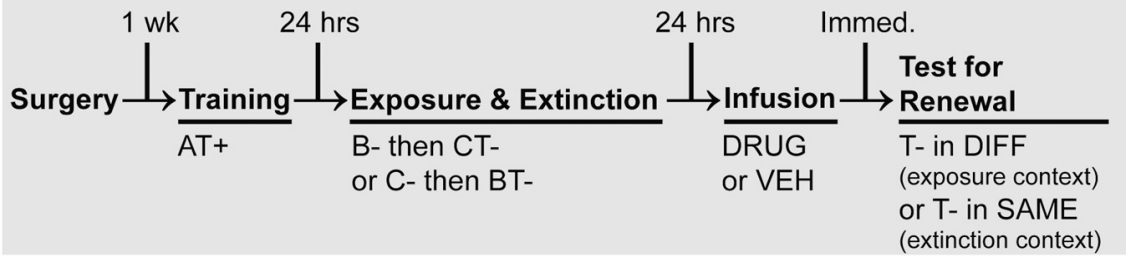

Figure 1. Experimental designs are read from left to right. Each phase of behavior is separated by 24 h; however, infusions occurred immediately prior to testing in both Experiments 1 and 2. A, B, C, experimental contexts; T, tone CS; +, US; -, no US.

after the final extinction session, rats underwent a reinstating shock session. First, rats were exposed to either Context A or B for 4 min in the absence of the CS or US; rats were returned to their home cages after this experience. Two hours later, rats were brought back to the laboratory and were placed in the other context (A or B; per group assignments) for a reinstating shock in that context. For the reinstating shock session, rats received a single, unsignaled footshock ( $1 \mathrm{~s}, 0.4 \mathrm{~mA})$ after $3 \mathrm{~min}$ in chambers. Rats remained in the chambers for 1 min after shock offset. Last, on Day 5, and immediately prior to retrieval testing, the rats were infused with muscimol or vehicle and transported to Context B to assess fear to the extinguished CS. Ten minutes after placement in Context $B$, the rats received five CS-only presentations (40 s ITIs). Rats remained in the testing chambers for 3 min following the final CS presentation.

\section{Experiment 2: effects of BNST inactivation on the expression of renewal}

Refer to Figure 1 for an illustration of the behavioral paradigm used for Experiment 2. Seventy-six rats were randomly assigned to drug (DRUG or VEH) and testing [different (DIFF) or SAME] conditions. Immediately prior to renewal testing, DRUG rats were infused with either 0.3 $\mu \mathrm{g}$ of muscimol $(1.0 \mu \mathrm{g} / \mu \mathrm{l}$ in $0.3 \mu \mathrm{l})$ per hemisphere (identical to Experiment 1) or $3.0 \mu \mathrm{g}$ of 2,3-dihydroxy-6nitro-7-sulfonyl-benzo[f]quinoxaline (NBQX; $10.0 \mu \mathrm{g} / \mu \mathrm{l}$ in $0.3 \mu \mathrm{l})$ per hemisphere. NBQX is a potent AMPA receptor and kainate receptor antagonist. We found no difference in the effects of NBQX or muscimol on conditional freezing at test $(F$ values $<0.1)$; therefore, we collapsed DRUG rats across this condition. Rats assigned to receive $\mathrm{VEH}$ were infused with $0.3 \mu \mathrm{l}$ of physiological saline. As in Experiment 1, all infusions were delivered at $0.3 \mu \mathrm{l} / \mathrm{min}$ for $1 \mathrm{~min}$. Rats assigned to the SAME condition were tested to the extinguished CS in the extinction context, whereas rats assigned to the DIFF condition experienced the extinguished CS outside of the extinction context (but in a familiar context).

On Day 1, all rats were conditioned with five CS-US pairings (CS: $10 \mathrm{~s}, 2 \mathrm{kHz}, 80 \mathrm{~dB}$ auditory tone; US: $2 \mathrm{~s}, 1$ $m A$ footshock) in Context $A$ (the procedure was identical to Experiment 1). Twenty-four hours later (Day 2), rats were first exposed for 35 min to the context (either Context B or Context $\mathrm{C}$ ) that was not hosting extinction; this ensured that exposure to all contexts was counterbalanced. Three hours later, the rats were extinguished in the alternate context (either Context B or Context C; counterbalanced by group). Three minutes after placement in the extinction context, the rats received 45 CS-only presentations (40 s ITIs); the rats remained in the chambers for 3 min after the final CS presentation. Twenty-four hours later, and immediately prior to renewal testing, rats were infused with either drug (muscimol or NBQX) or VEH and transported to the appropriate test context (which was either the same as or different from the extinction context). Responding at the test was not affected by whether the renewal context was B or $\mathrm{C}(F$ values $<0.1)$; the data are collapsed across this condition. Three minutes after placement in the test context, rats received five CS-only presentations (40 s ITIs). Rats remained in the testing chamber for 3 min after the final CS-only presentation.

\section{Intracranial infusions}

Rats were transported in 5-gallon buckets to a procedure room within the colony for drug infusions. The obturators were removed from the guide cannulae and stainless steel injection needles (33 gauge, $9 \mathrm{~mm}$; extending $1 \mathrm{~mm}$ beyond the end of the guide) were inserted. Each injector (Small Parts) was attached to polyethylene tubing (PE-20; Braintree Scientific), which in turn was connected to a gastight $10 \mu \mathrm{l}$ syringe (Hamilton, Co.). Syringes were mounted in an infusion pump (KD Scientific). After insertion of the injectors, the rats were returned to the buckets where they remained unrestrained during the infusion procedure. After the infusion, the injection needles remained in the guide cannulae for $1 \mathrm{~min}$ before being removed; clean obturators were inserted into the guides, and the rats were transported to the conditioning chambers. 


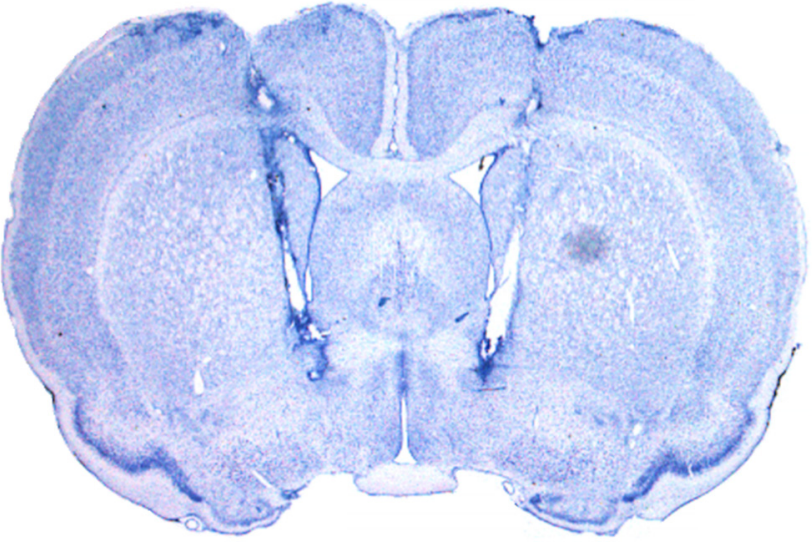

Figure 2 Representative photomicrograph of a thionin-stained coronal section $(40 \mu \mathrm{m})$ from the brain of a rat with injector tips terminating within the bed nucleus of the stria terminalis.

\section{Histological procedures}

Within 1 week after the final retention test, the rats were overdosed with sodium pentobarbital (Fatal Plus; 100 $\mathrm{mg} / \mathrm{ml}, 0.5 \mathrm{ml}$, i.p.) and perfused. Transcardial perfusions were performed with physiological saline followed by $10 \%$ formalin solution. Brains were removed from the skull and stored in $10 \%$ formalin for $24 \mathrm{~h}$ at $4^{\circ} \mathrm{C}$ followed by $30 \%$ sucrose-formalin for at least $3 \mathrm{~d}$ before sectioning. Brain tissue was flash frozen with dry ice and sectioned at $40 \mu \mathrm{m}$ on a cryostat (Leica Microsystems) at $-20^{\circ} \mathrm{C}$. Sections were wet mounted to microscope slides and stained with $0.25 \%$ thionin to identify cannula tracts and to localize injection sites in the tissue. Photomicrographs of the sections ( $10 \times$ magnification) were captured and digitized using a Leica MZFLIII microscope. Figure 2 shows a representative coronal section from a rat with injector tips localized to the BNST.

\section{Data analyses}

Freezing served as the index of fear for all behavioral analyses. All data were submitted to ANOVA (in-text lowercase superscripts correspond to the analyses in Table 1). Post hoc comparisons (Fisher's protected least significant difference test) on individual group means were calculated after a significant omnibus $F$ ratio in the ANOVA; $\alpha$ was set at 0.05 . Rats were excluded from the analyses if they failed to extinguish by the final extinction session (mean freezing, $>50 \%$ ) or if mean pre-CS freezing during the retrieval test was $>50 \%$. Based on these criteria, 10 rats were excluded from Experiment 2. Unless noted otherwise, freezing data (as a percentage of the total time spent immobile) were analyzed across the trials in Figures 4, 5.

\section{Results}

\section{Histology}

Injection sites within the BNST are illustrated in Figure 3. For Experiment 1 (Fig. 3A), 16 injectors terminated within the anterior lateral division of the BNST (which includes the anterolateral area, juxtacapsular nucleus, oval nucleus, and rhomboid nucleus), 4 were localized to the anterior medial BNST (which includes the anterodorsal area and central core of the anterodorsal area), 5 were localized to the anterior ventral BNST (which includes the anteroventral area, dorsolateral nucleus, dorsomedial nucleus, fusiform nucleus, magnocellular nucleus, subcommissural zone, and ventral nucleus), and 9 were located in the anterior commissure within the anterior BNST (Swanson, 1998). This yielded the following groups for the final analyses: MUS, $n=7$; VEH, $n=10$. Cannulae missed their targets in 15 animals; these animals (MUS, $n=9$; $\mathrm{VEH}, n=6)$ were analyzed separately to determine whether off-target drug infusions affected reinstatement.

For Experiment 2, 45 animals received bilateral injectors within the BNST. Of these animals, 10 subjects were excluded based on the behavioral criteria described above, yielding the following groups: DRUG/DIFF, $n=11$; DRUG/SAME, $n=6$; VEH/DIFF, $n=8$; and VEH/SAME, $n$ $=10$. Accordingly, 70 injection sites from 35 animals are illustrated in Figure 3B. Thirteen injectors were localized to the anterior lateral division of the BNST, 4 terminated within the anterior medial division, 22 terminated within the anterior ventral division, 5 terminated in the anterior commissure within the anterior BNST, and 26 terminated within the posterior division of the BNST (which includes

Table 1 Statistical table

\begin{tabular}{|c|c|c|c|}
\hline In-text letter & Data structure & Type of test & Power \\
\hline a & Normal distribution & One-way repeated-measures ANOVA (conditioning trials) & 1.000 \\
\hline b & Normal distribution & One-way repeated-measures ANOVA [extinction trials (Day 2)] & 1.000 \\
\hline c & Normal distribution & One-way repeated-measures ANOVA [extinction trials (Day 3)] & 1.000 \\
\hline d & Normal distribution & One-way repeated-measures ANOVA (reinstating shock trials) & 1.000 \\
\hline e & Normal distribution & One-way repeated-measures ANOVA (infusion group across baseline at test) & 0.968 \\
\hline f & Normal distribution & One-way repeated-measures ANOVA (infusion group across testing) & 0.957 \\
\hline g & Normal distribution & One-way repeated-measures ANOVA (test trials) & 0.993 \\
\hline h & Normal distribution & $\begin{array}{l}\text { One-way repeated-measures ANOVA (final extinction block vs mean } \\
\text { responding at test for VEH animals) }\end{array}$ & 0.935 \\
\hline i & Normal distribution & One-way repeated-measures ANOVA (conditioning trials) & 1.000 \\
\hline j & Normal distribution & One-way repeated-measures ANOVA (extinction trials) & 1.000 \\
\hline $\mathrm{k}$ & Normal distribution & One-way repeated-measures ANOVA (renewal group across testing) & 0.951 \\
\hline I & Normal distribution & Two-way repeated-measures ANOVA (testing trials $\times$ renewal group) & 0.858 \\
\hline $\mathrm{m}$ & Normal distribution & $\begin{array}{l}\text { One-way repeated-measures ANOVA (final extinction block vs mean } \\
\text { responding at test for DIFF animals) }\end{array}$ & 0.977 \\
\hline
\end{tabular}



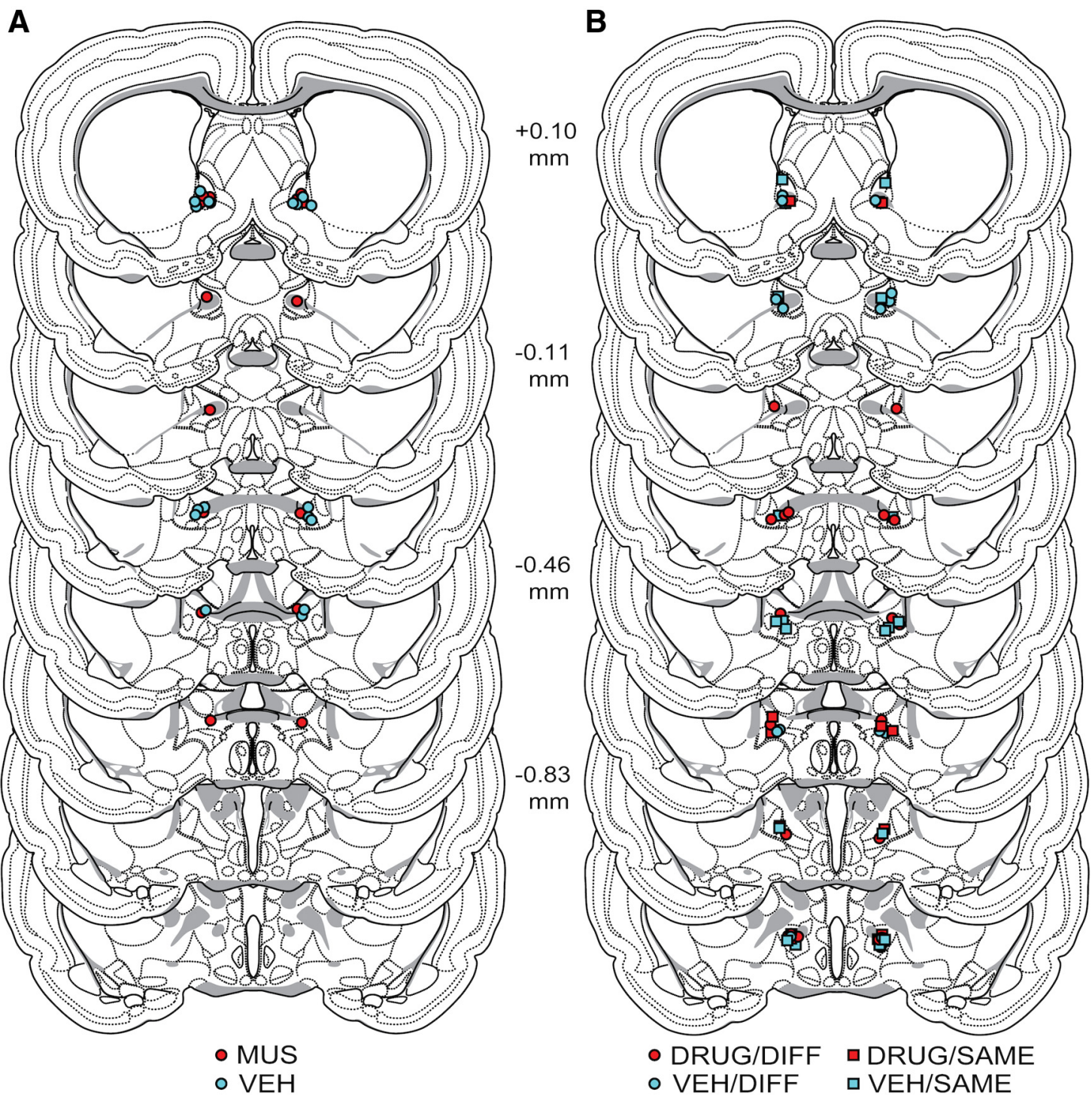

Figure 3 Illustration of cannula placement sites in the bed nucleus of the stria terminalis. Placements are shown for all rats included in the final analyses for Experiment $1(\boldsymbol{A})$ and Experiment $2(\boldsymbol{B})$. Adapted from Swanson (1998). Distances shown are relative to bregma.

the interfascicular nucleus, principal nucleus, and transverse nucleus).

\section{Experiment 1: BNST inactivation prevents reinstatement of fear to an extinguished CS}

Rats exhibited reliable fear conditioning to the auditory CS (Fig. 4). This impression was confirmed in an ANOVA by a significant main effect of trial $\left(F_{(5,75)}=9.1 ; p<\right.$ $0.0001^{\mathrm{a}}$ ); freezing behavior increased across the conditioning session, and there were no group differences on this measure $(F$ values $<1)$. Over the next $2 \mathrm{~d}$, all rats were extinguished to the $\mathrm{CS}$ in Context $\mathrm{A}$. During the first extinction session (Fig. 4), there was a significant main effect of trial $\left(F_{(10,150)}=10.6 ; p<0.0001^{\mathrm{b}}\right)$ as freezing behavior decreased over the course of the extinction session; there were no group differences in extinction rate or magnitude ( $F$ values $<1$ ). During the second extinction session (Fig. 4), there again was a significant main effect of trial $\left(F_{(10,150)}=7.9 ; p<0.0001^{\mathrm{C}}\right)$, reflecting decreases in freezing behavior over the course of the session; again, there were no group differences in extinction rate or magnitude $(F$ values $<1)$. On Day 4 , all rats received an unsignaled footshock to reinstate fear to the extinguished CS (Fig. 4). Freezing behavior reliably increased after footshock. This impression was confirmed in an ANOVA that revealed a significant main effect of trial for freezing across the preshock and postshock periods $\left(F_{(1,15)}=\right.$ 49.5; $\left.p<0.0001^{\mathrm{d}}\right)$. Shock-induced increases in fear on Day 4 were similar across drug and context conditions ( $F$ values $<2$ ).

Twenty-four hours after the reinstatement shock, rats were infused with muscimol or vehicle into the BNST and immediately placed in Context B for a CS retrieval test. During the $10 \mathrm{~min}$ baseline prior to the first CS presenta- 


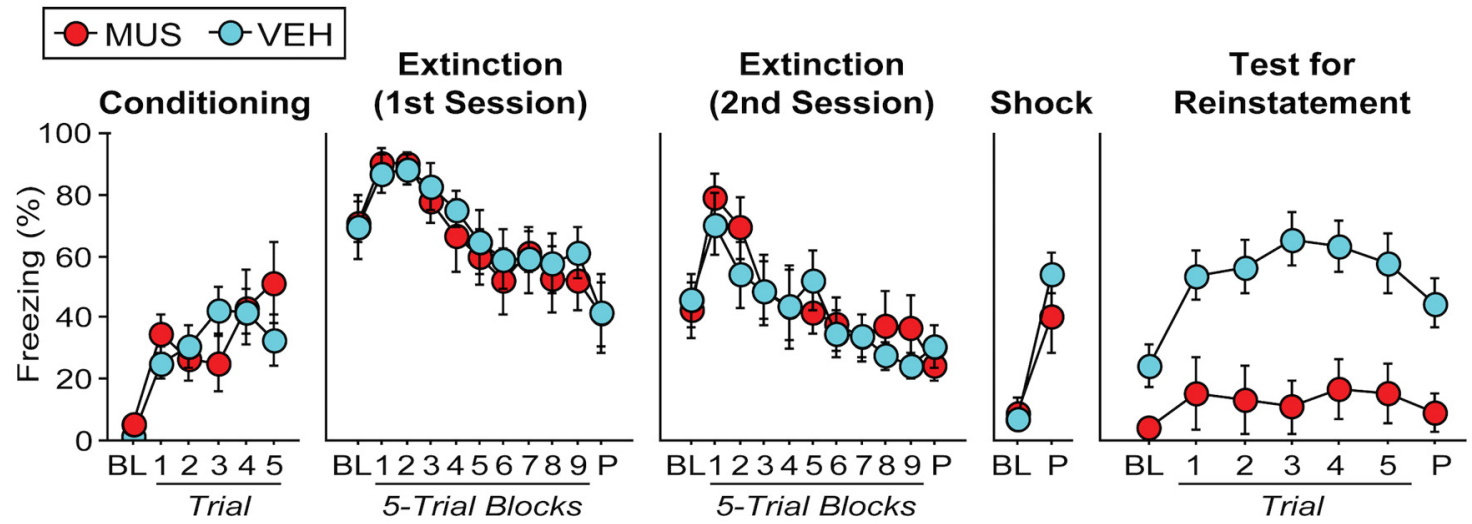

Figure 4 Pharmacological inactivation of the BNST prevents reinstatement (Experiment 1). Conditioning, Mean ( \pm SEM) percentage of freezing during the $3 \mathrm{~min}$ baseline $(\mathrm{BL})$ and in the $60 \mathrm{~s}$ interstimulus interval following each CS-US pairing. Extinction (First Session), Mean ( \pm SEM) percentage freezing during a $3 \mathrm{~min} B L$ and across nine extinction blocks (each block represents average responding during the $30 \mathrm{~s}$ post-CS intervals after five extinction trials). The rats remained in the chambers for $150 \mathrm{~s}$ after the final CS presentation $(P)$. Extinction (Second Session), Mean ( \pm SEM) percentage freezing for the second day of extinction training (trials are equivalent to the first extinction day). Shock, Mean ( \pm SEM) percentage freezing during the 3 min BL period before unsignaled footshock and during the $1 \mathrm{~min}$ postshock period. Test for Reinstatement, Mean ( \pm SEM) percentage freezing during the final 3 min of the BL period immediately prior to CS onset and during five $30 \mathrm{~s}$ interstimulus intervals after each test trial; the rats remained in the chambers for $150 \mathrm{~s}$ after the final CS.

tion, vehicle-treated rats exhibited significantly greater levels of freezing than muscimol-treated animals (VEH, $31.108 \pm 5.644 \%$; MUS, $3.968 \pm 1.409 \%)$. This was confirmed in the ANOVA by a significant main effect of drug across baseline freezing $\left(F_{(1,50)}=15.423 ; p=\right.$ $0.0013^{\mathrm{e}}$ ). In addition, and as shown in Figure 4, VEHtreated rats exhibited significantly greater levels of fear to the extinguished CS than MUS-treated animals. This impression was confirmed in the ANOVA by a main effect of drug across all testing trials $\left(F_{(1,90)}=14.446 ; p=0.0017^{f}\right)$. There was a significant main effect of trial $\left(F_{(6,90)}=5.737\right.$; $p<0.0001^{9}$ ) insofar as freezing behavior increased on average after presentation of the CS. Freezing to the CS during the retrieval test in vehicle-treated rats was significantly greater than during the final block of extinction, indicating successful reinstatement of extinguished fear $\left(F_{(1,9)}=14.607 ; p=0.0041^{\mathrm{h}}\right)$. Importantly, reinstatement impairments were obtained only in rats with cannula placements in the BNST. Muscimol infusion in rats with off-target placements that missed the BNST exhibited normal reinstatement and did not differ from controls during either the baseline or CS periods ( $F$ values $<0.5$ ). Overall, these data reveal that BNST inactivation reduced both contextual freezing and the reinstatement of fear to an extinguished CS.

\section{Experiment 2: BNST inactivation does not alter the expression of fear renewal}

As shown in Figure 5, rats exhibited reliable fear conditioning. This impression was confirmed in the ANOVA by a significant main effect of trial $\left(F_{(5,155)}=31.2 ; p<\right.$ $0.0001^{i}$ ); freezing behavior increased over the course of conditioning, and the groups did not differ from one another $(F$ values $<1)$. Twenty-four hours later, rats significantly reduced their fear across extinction trials (Fig. 5; main effect of trial, $\left.F_{(10,310)}=50.6 ; p<0.0001^{1}\right)$. Extinction of fear on Day 2 was similar across group assignments ( $F$ values $<1$ ).

On Day 3, rats were infused with either drug or vehicle immediately before receiving a retrieval test in the extinction context (SAME) or in the context in which extinction did not occur (DIFF). As indicated in Figure 5, both VEHand DRUG-treated rats exhibited robust fear renewal in the DIFF context relative to the low levels of freezing expressed by rats in the SAME context. BNST inactivation did not attenuate the renewal of fear to the extinguished CS. This impression was confirmed in the ANOVA by a main effect of context $\left(F_{(1,186)}=12.843 ; p=0.0011^{\mathrm{k}}\right)$ such that rats in the DIFF condition exhibited significantly more freezing across test trials than those in the SAME condition (regardless of drug condition). A significant trial $\times$ context interaction $\left(F_{(6,186)}=2.647 ; p=0.0173^{\prime}\right)$ indicated that DIFF rats exhibited greater freezing after CS onset compared to SAME rats. Moreover, DIFF rats (but not SAME rats; $F$ values $<0.5$ ) exhibited significantly more freezing across test trials relative to the final block of extinction $\left(F_{(1,18)}=16.005 ; p=0.0008^{\mathrm{m}}\right)$, indicating robust renewal of fear. Hence, BNST inactivation did not impair either the renewal or expression of fear to an extinguished auditory CS.

\section{Discussion}

The current study reveals the novel finding that the BNST plays a specific role in the shock-induced reinstatement of extinguished fear; BNST inactivation did not affect the renewal of extinguished fear that accompanies a change in context. Deficits in the reinstatement of extinguished fear were paralleled by reductions in the expression of contextual freezing after BNST inactivation. These results are consistent with an earlier report (Waddell et al., 2006) revealing that neurotoxic lesions of the BNST impair the shock-induced reinstatement of extinguished fear. Addi- 


\section{-O-DEUG/DIFF $\quad$ - VEHIDF $\square$-DRUG/SAME $\quad$ - VEH/SAME}
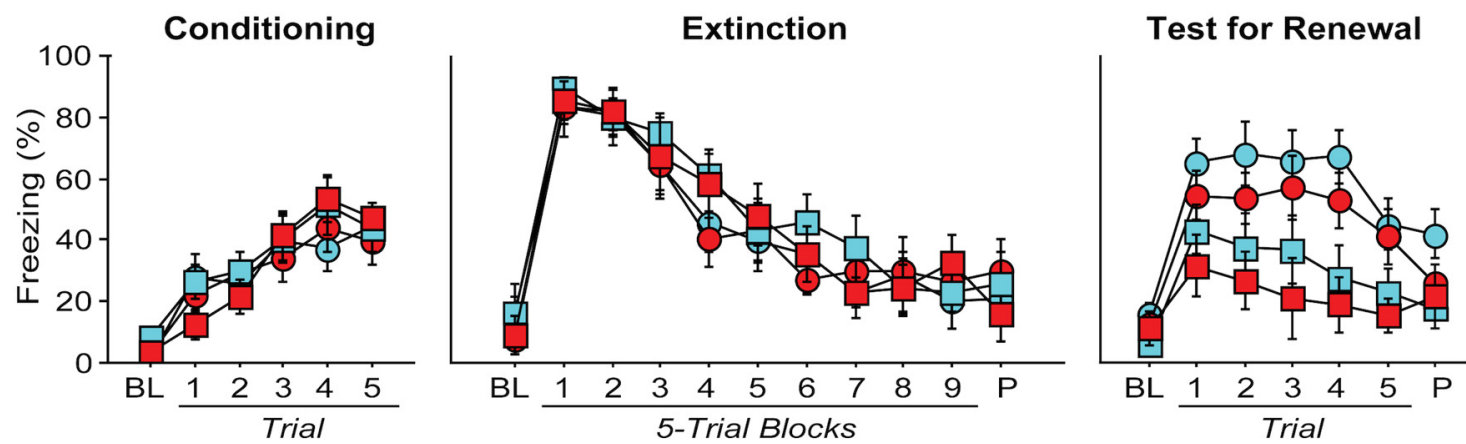

Figure 5 Pharmacological inactivation of the BNST does not prevent renewal (Experiment 2). Conditioning, Mean percentage of freezing during the $3 \mathrm{~min}$ baseline $(\mathrm{BL})$ and in the $60 \mathrm{~s}$ interstimulus interval following each CS-US pairing. Extinction, Mean ( \pm SEM) percentage freezing during a $3 \mathrm{~min} B L$ and across nine extinction blocks. Each block represents the average responding during the $30 \mathrm{~s}$ post-CS intervals after five extinction trials. The rats remained in the chambers for $150 \mathrm{~s}$ after the final CS presentation (P). Test for Renewal, Mean ( \pm SEM) percentage freezing during the 3 min baseline period immediately prior to CS onset and during five $30 \mathrm{~s}$ interstimulus intervals after each test trial; the rats remained in the chambers for $150 \mathrm{~s}$ after the final CS.

tionally, our work parallels findings revealing that the BNST is necessary for shock-induced reinstatement of extinguished drug-seeking behavior (Erb and Stewart, 1999; Erb et al., 2001; see also Leri et al., 2002; Buffalari and See, 2011). Collectively, these data suggest that the BNST has a critical role in the relapse of extinguished behaviors caused by the experience of aversive stimuli (for review, see Smith and Aston-Jones, 2008; Silberman and Winder, 2013; Stamatakis et al., 2014).

Although BNST inactivation impaired fear reinstatement, it did not affect fear renewal despite the fact that the extent of relapse was similar between experiments. This reveals that deficits in reinstatement are not due to impairments in the expression of freezing per se. Indeed, this pattern of results is consistent with other reports indicating that the BNST has a selective role in the expression of fear to contextual compared to discrete CSs (LeDoux et al., 1988; Walker and Davis, 1997; Sullivan et al., 2004; Waddell et al., 2006, 2008; Zimmerman and Maren, 2011; Sink et al., 2013; see also Duvarci et al., 2009; Haufler et al., 2013). Importantly, pretraining lesions of the BNST do not disrupt the acquisition of conditioned fear to discrete CSs (LeDoux et al., 1988; Waddell et al., 2006), nor do post-training lesions of the BNST affect the expression of conditioned fear to discrete CSs (Sullivan et al., 2004). However, BNST lesions attenuate the expression of fear to shock-associated contexts (Sullivan et al., 2004) and attenuate the expression of fear responses to long-duration CSs (i.e., 10 min tones paired with shock; Waddell et al., 2006). Additionally, Sullivan et al. (2004) reported that rats with BNST lesions exhibited blunted corticosterone responding during exposure to a conditioned context (see also Resstel et al., 2008). Hence, it is believed that BNST inactivation prevents reinstatement by reducing the expression of contextual fear, which is thought to be essential for the reinstatement effect (Bouton and Bolles, 1979; Westbrook et al., 2002; Bouton et al., 2006; Waddell et al., 2006).
A key finding in the present study is that BNST inactivation did not affect fear renewal. Unlike reinstatement, however, renewal does not require contextual fear. Indeed, fear renewal can be obtained in contexts that have never hosted shock (e.g., "ABC" or "AAB" renewal; Bouton and Bolles, 1979; Bouton and Ricker, 1994; Harris et al., 2000; Westbrook et al., 2002; Corcoran and Maren, 2004; Holmes and Westbrook, 2013; Jin and Maren, 2015). Renewal also occurs in shock-associated contexts that have themselves undergone extinction and no longer support contextual fear (e.g., "ABA" renewal; Bouton and King, 1983; Vansteenwegen et al., 2005; Effting and Kindt, 2007; Knox et al., 2012; Polack et al., 2013; Holmes and Westbrook, 2014). These findings support the idea that renewal depends not on direct context-US associations, but on a contextual retrieval process that informs the animal of what a CS means in a particular context (Bouton and Bolles, 1979; Bouton and King, 1983; Bouton and Peck, 1989; Holland, 1992; Bouton, 1993; Bouton and Ricker, 1994; Harris et al., 2000; Bouton et al., 2006; Ji and Maren, 2007; Maren et al., 2013; Vervliet et al., 2013b; Delamater and Westbrook, 2014). Importantly, the present results strengthen this view insofar as renewal of fear was immune to BNST inactivation (a manipulation that impairs contextual fear). Considerable work now reveals that this contextual retrieval process depends on a circuit involving the amygdala, hippocampus, and prefrontal cortex (Corcoran and Maren, 2004; Ji and Maren, 2005, 2007; Herry et al., 2008; Knapska and Maren, 2009; Orsini et al., 2011, 2013; Zelikowsky et al., 2012; Maren, 2014; Jin and Maren, 2015).

An important issue that has yet to be resolved is which subregions of the BNST contribute to the effects we have observed in the present study. Indeed, the BNST is heterogeneous in structure, and different subregions within the BNST appear to make unique contributions to fear and anxiety (Walter et al., 1991; Dong et al., 2001a; Dong and Swanson, 2003, 2004a,b; Choi et al., 2007; Jennings 
et al., 2013; Kim et al., 2013). For example, Kim et al. (2013) showed that photostimulation of the oval nucleus of the BNST resulted in anxiety-related behaviors, while photostimulation of the anterodorsal region of the BNST resulted in anxiolytic behaviors. Jennings et al. (2013) demonstrated that photostimulation of glutamatergic projections of the ventral BNST to the ventral tegmental area (VTA) produced increases in anxiety, whereas photostimulation of GABAergic BNST projections to the VTA was anxiolytic. In the present study, cannula placements terminated primarily within the anterior portion of the BNST (particularly the anterior lateral and anterior ventral divisions of the BNST), though several rats received infusions within the posterior division of the BNST in Experiment 2. The spread of drug likely affected multiple BNST nuclei in these areas. Circuit-selective chemogenetic or optogenetic techniques would help to clarify the specific BNST subregions contributing to fear reinstatement (Sparta et al., 2013).

In humans and other animals, the BNST shares connections with several important emotion-regulating regions in the brain, including the amygdala, dorsal raphe nucleus, hippocampus, hypothalamus, nucleus accumbens, prefrontal cortex, and ventral tegmental area (Swanson and Cowan, 1977; Weller and Smith, 1982; Phelix et al., 1992; Sun and Cassell, 1993; Dong et al., 2001a,b; Dong and Swanson, 2003, 2004a,b; Jalabert et al., 2009; Crestani et al., 2013; Avery et al., 2014; Roman et al., 2014; Krüger et al., 2015). Not surprisingly, the BNST has been implicated in various depression- and anxiety-related behaviors (for review, see Walker and Davis, 2008; Hammack et al., 2009, 2010,2012; Walker et al., 2009; Davis et al., 2010; McElligott et al., 2013; Adhikari, 2014; Kash et al., 2015). Importantly, the BNST modulates hypothalamicpituitary-adrenal axis activity, including corticosterone release, via its connections with the hypothalamic paraventricular nucleus (Cullinan et al., 1993; Herman et al., 1994; Sullivan et al., 2004; Choi et al., 2007; Crestani et al., 2013). Corticosterone release is correlated with both the acquisition and expression of conditioned fear (Campeau et al., 1997; Pugh et al., 1997; Cordero et al., 1998; Roozendaal et al., 2006; Marchand et al., 2007). Hence, BNST lesions might influence reinstatement by limiting the modulatory effects of corticosterone on fear expression to an extinguished CS. Alternatively, the BNST is positioned to directly influence freezing behavior via its projections to the amygdala and periaqueductal gray (Dong et al., 2001a; Dong and Swanson, 2003, 2004a,b; Fendt et al., 2003; Asok et al., 2013). In this way, the BNST might directly drive reinstatement of fear to an extinguished CS by driving amygdaloid and periaqueductal gray circuits involved in fear expression. In either case, BNST-mediated modulation of contextual fear might summate with fear to the extinguished CS to yield reinstatement.

In conclusion, the present results reveal that distinct neural circuits mediate different forms of fear relapse. Here we show that the BNST is especially important for reinstatement, a form of relapse produced by the exposure of animals to aversive stimuli. Hence, selective ma- nipulations of the BNST may be particularly effective in preventing fear relapse in aversive contexts. Ultimately, appreciating the circumstances that give rise to the return of fear will help in isolating circuit-specific therapies for combating fear relapse.

\section{References}

Adhikari A (2014) Distributed circuits underlying anxiety. Front Behav Neurosci 8:112. CrossRef Medline

Asok A, Ayers LW, Awoyemi B, Schulkin J, Rosen JB (2013) Immediate early gene and neuropeptide expression following exposure to the predator odor 2,5-dihydro-2,4,5-trimethylthiazoline (TMT). Behav Brain Res 248:85-93. CrossRef Medline

Avery SN, Clauss JA, Winder DG, Woodward N, Heckers S, Blackford JU (2014) BNST neurocircuitry in humans. Neuroimage 91: 311-323. CrossRef Medline

Barad M (2005) Fear extinction in rodents: basic insight to clinical promise. Curr Opin Neurobiol 15:710-715. CrossRef Medline

Boschen MJ, Neumann DL, Waters AM (2009) Relapse of successfully treated anxiety and fear: theoretical issues and recommendations for clinical practice. Aust N Z J Psychiatry 43:89-100. CrossRef Medline

Bouton ME (1993) Context, time, and memory retrieval in the interference paradigms of Pavlovian learning. Psychol Bull 114:80-99. Medline

Bouton ME (2002) Context, ambiguity, and unlearning: sources of relapse after behavioral extinction. Biol Psychiatry 52:976-986. Medline

Bouton ME (2004) Context and behavioral processes in extinction. Learn Mem 11:485-494. CrossRef Medline

Bouton ME (2014) Why behavior change is difficult to sustain. Prev Med 68:29-36. [PMC] [10.1016/j.ypmed.2014.06.010]

Bouton ME, Bolles RC (1979) Role of conditioned contextual stimuli in reinstatement of extinguished fear. J Exp Psychol Anim Behav Process 5:368-378. Medline

Bouton ME, King DA (1983) Contextual control of the extinction of conditioned fear: tests for the associative value of the context. $J$ Exp Psychol Anim Behav Process 9:248-265. Medline

Bouton ME, Peck CA (1989) Context effects on conditioning, extinction, and reinstatement in an appetitive conditioning preparation. Anim Learn Behav 17:188-198. CrossRef

Bouton ME, Ricker ST (1994) Renewal of extinguished responding in a second context. Anim Learn Behav 22:317-324. CrossRef

Bouton ME, Westbrook RF, Corcoran KA, Maren S (2006) Contextual and temporal modulation of extinction: behavioral and biological mechanisms. Biol Psychiatry 60:352-360. CrossRef Medline

Buffalari DM, See RE (2011) Inactivation of the bed nucleus of the stria terminalis in an animal model of relapse: effects on conditioned cue-induced reinstatement and its enhancement by yohimbine. Psychopharmacology (Berl) 213:19-27. CrossRef

Campeau S, Falls WA, Cullinan WE, Helmreich DL, Davis M, Watson SJ (1997) Elicitation and reduction of fear: behavioural and neuroendocrine indices and brain induction of the immediate-early gene c-fos. Neuroscience 78:1087-1104. Medline

Chang $\mathrm{CH}$, Knapska E, Orsini CA, Rabinak CA, Zimmerman JM, Maren S (2009) Fear extinction in rodents. Curr Protoc Neurosci Chapter 8:Unit8.23. CrossRef Medline

Choi DC, Furay AR, Evanson NK, Ostrander MM, Ulrich-Lai YM, Herman JP (2007) Bed nucleus of the stria terminalis subregions differentially regulate hypothalamic-pituitary-adrenal axis activity: implications for the integration of limbic inputs. J Neurosci 27: 2025-2034. CrossRef Medline

Corcoran KA, Maren S (2004) Factors regulating the effects of hippocampal inactivation on renewal of conditional fear after extinction. Learn Mem 11:598-603. CrossRef Medline

Cordero MI, Merino JJ, Sandi C (1998) Correlational relationship between shock intensity and corticosterone secretion on the es- 
tablishment and subsequent expression of contextual fear conditioning. Behav Neurosci 112:885-891. Medline

Crestani CC, Alves FH, Gomes FV, Resstel LB, Correa FM, Herman JP (2013) Mechanisms in the bed nucleus of the stria terminalis involved in control of autonomic and neuroendocrine functions: a review. Curr Neuropharmacol 11:141-159. CrossRef Medline

Cullinan WE, Herman JP, Watson SJ (1993) Ventral subicular interaction with the hypothalamic paraventricular nucleus: evidence for a relay in the bed nucleus of the stria terminalis. J Comp Neurol 332:1-20. CrossRef Medline

Davis M, Walker DL, Miles L, Grillon C (2010) Phasic vs sustained fear in rats and humans: role of the extended amygdala in fear vs anxiety. Neuropsychopharmacology 35:105-135. CrossRef Medline

Delamater AR, Westbrook RF (2014) Psychological and neural mechanisms of experimental extinction: a selective review. Neurobiol Learn Mem 108:38-51. CrossRef Medline

Deschaux O, Zheng X, Lavigne J, Nachon O, Cleren C, Moreau JL, Garcia R (2013) Post-extinction fluoxetine treatment prevents stress-induced reemergence of extinguished fear. Psychopharmacology (Berl) 225:209-216. CrossRef Medline

Dong HW, Petrovich GD, Swanson LW (2001b) Topography of projections from amygdala to bed nuclei of the stria terminalis. Brain Res Brain Res Rev 38:192-246. Medline

Dong HW, Petrovich GD, Watts AG, Swanson LW (2001a) Basic organization of projections from the oval and fusiform nuclei of the bed nuclei of the stria terminalis in adult rat brain. J Comp Neurol 436:430-455. Medline

Dong HW, Swanson LW (2003) Projections from the rhomboid nucleus of the bed nuclei of the stria terminalis: implications for cerebral hemisphere regulation of ingestive behaviors. J Comp Neurol 463:434-472. CrossRef Medline

Dong HW, Swanson LW (2004a) Organization of axonal projections from the anterolateral area of the bed nuclei of the stria terminalis. J Comp Neurol 468:277-298. CrossRef Medline

Dong HW, Swanson LW (2004b) Projections from bed nuclei of the stria terminalis, posterior division: implications for cerebral hemisphere regulation of defensive and reproductive behaviors. J Comp Neurol 471:396-433. CrossRef Medline

Duvarci S, Bauer EP, Paré D (2009) The bed nucleus of the stria terminalis mediates interindividual variations in anxiety and fear. $\mathrm{J}$ Neurosci 29:10357-10361. CrossRef Medline

Effting M, Kindt M (2007) Contextual control of human fear associations in a renewal paradigm. Behav Res Ther 45:2002-2018. CrossRef Medline

Erb S, Shaham Y, Stewart J (2001) Stress-induced relapse to drug seeking in the rat: role of the bed nucleus of the stria terminalis and amygdala. Stress 4:289-303. Medline

Erb S, Stewart J (1999) A role for the bed nucleus of the stria terminalis, but not the amygdala, in the effects of corticotropinreleasing factor on stress-induced reinstatement of cocaine seeking. J Neurosci 19:RC35. Medline

Fendt M, Endres T, Apfelbach R (2003) Temporary inactivation of the bed nucleus of the stria terminalis but not of the amygdala blocks freezing induced by trimethylthiazoline, a component of fox feces. $J$ Neurosci 23:23-28. Medline

Fendt M, Fanselow MS (1999) The neuroanatomical and neurochemical basis of conditioned fear. Neurosci Biobehav Rev 23:743-760. Medline

Fitzgerald PJ, Seemann JR, Maren S (2014) Can fear extinction be enhanced? A review of pharmacological and behavioral findings. Brain Res Bull 105:46-60. CrossRef Medline

Goode TD, Kim JJ, Maren S (2015) Relapse of extinguished fear after exposure to a dangerous context is mitigated by testing in a safe context. Learn Mem 22:170-178. CrossRef Medline

Goode TD, Maren S (2014) Animal models of fear relapse. ILAR J 55:246-258. CrossRef Medline

Halladay LR, Zelikowsky M, Blair HT, Fanselow MS (2012) Reinstatement of extinguished fear by an unextinguished conditional stimulus. Front Behav Neurosci 6:18. CrossRef Medline
Hammack SE, Cooper MA, Lezak KR (2012) Overlapping neurobiology of learned helplessness and conditioned defeat: implications for PTSD and mood disorders. Neuropharmacology 62:565-575. CrossRef Medline

Hammack SE, Guo JD, Hazra R, Dabrowska J, Myers KM, Rainnie DG (2009) The response of neurons in the bed nucleus of the stria terminalis to serotonin: implications for anxiety. Prog Neuropsychopharmacology Biol Psychiatry 33:1309-1320. CrossRef Medline

Hammack SE, Roman CW, Lezak KR, Kocho-Shellenberg M, Grimmig B, Falls WA, Braas K, May V (2010) Roles for pituitary adenylate cyclase-activating peptide (PACAP) expression and signaling in the bed nucleus of the stria terminalis (BNST) in mediating the behavioral consequences of chronic stress. J Mol Neurosci 42: 327-340. CrossRef Medline

Haroutunian V, Riccio DC (1977) Effect of arousal conditions during reinstatement treatment upon learned fear in young rats. Dev Psychobiol 10:25-32. CrossRef Medline

Harris JA, Jones ML, Bailey GK, Westbrook RF (2000) Contextual control over conditioned responding in an extinction paradigm. J Exp Psychol Anim Behav Process 26:174-185. CrossRef

Haufler D, Nagy FZ, Pare D (2013) Neuronal correlates of fear conditioning in the bed nucleus of the stria terminalis. Learn Mem 20:633-641. CrossRef Medline

Herman JP, Cullinan WE, Watson SJ (1994) Involvement of the bed nucleus of the stria terminalis in tonic regulation of the paraventricular hypothalamic CRH and AVP mRNA expression. J Neuroendocrinol 6:433-442. Medline

Hermans D, Craske MG, Mineka S, Lovibond PF (2006) Extinction in human fear conditioning. Biol Psychiatry 60:361-368. CrossRef Medline

Herry C, Ciocchi S, Senn V, Demmou L, Müller C, Lüthi A (2008) Switching on and off fear by distinct neuronal circuits. Nature 454:600-606. CrossRef Medline

Holland PC (1992) Occasion setting in Pavlovian conditioning. In: The psychology of learning and motivation (Medin DL, ed), pp 69-125. San Diego: Academic.

Holmes NM, Westbrook RF (2013) Extinction of reinstated or ABC renewed fear responses renders them resistant to subsequent ABA renewal. J Exp Psychol Anim Behav Process 39:208-220. CrossRef Medline

Holmes NM, Westbrook RF (2014) ABA renewal is greater when extinction occurs in the same context as cue pre-exposure. J Exp Psychol Anim Learn Cogn 40:369-379. CrossRef Medline

Hooley JM (2007) Expressed emotion and relapse of psychopathology. Annu Rev Clin Psychol 3:329-352. CrossRef Medline

Jalabert M, Aston-Jones G, Herzog E, Manzoni O, Georges F (2009) Role of the bed nucleus of the stria terminalis in the control of ventral tegmental area dopamine neurons. Prog Neuropsychopharmacol Biol Psychiatry 33:1336-1346. CrossRef Medline

Jennings JH, Sparta DR, Stamatakis AM, Ung RL, Pleil KE, Kash TL, Stuber GD (2013) Distinct extended amygdala circuits for divergent motivational states. Nature 496:224-228. CrossRef Medline

Ji J, Maren S (2005) Electrolytic lesions of the dorsal hippocampus disrupt renewal of conditional fear after extinction. Learn Mem 12:270-276. CrossRef Medline

Ji J, Maren S (2007) Hippocampal involvement in contextual modulation of fear extinction. Hippocampus 17:749-758. CrossRef Medline

Jin J, Maren S (2015) Fear renewal preferentially activates ventral hippocampal neurons projecting to both amygdala and prefrontal cortex in rats. Sci Rep 5:8388. CrossRef Medline

Kash TL, Pleil KE, Marcinkiewcz CA, Lowery-Gionta EG, Crowley N, Mazzone C, Sugam J, Hardaway JA, McElligott ZA (2015) Neuropeptide regulation of signaling and behavior in the BNST. Mol Cells 38:1-13. CrossRef Medline

Kehoe EJ, Macrae M (1997) Savings in animal learning: implications for relapse and maintenance after therapy. Behav Ther 28:141155. CrossRef 
Kim SY, Adhikari A, Lee SY, Marshel JH, Kim CK, Mallory CS, Lo M, Pak S, Mattis J, Lim BK, Malenka RC, Warden MR, Neve R, Tye KM, Deisseroth K (2013) Diverging neural pathways assemble a behavioural state from separable features in anxiety. Nature 496: 219-223. CrossRef Medline

Knapska E, Maren S (2009) Reciprocal patterns of c-Fos expression in the medial prefrontal cortex and amygdala after extinction and renewal of conditioned fear. Learn Mem 16:486-493. CrossRef Medline

Knox D, George SA, Fitzpatrick CJ, Rabinak CA, Maren S, Liberzon I (2012) Single prolonged stress disrupts retention of extinguished fear in rats. Learn Mem 19:43-49. CrossRef Medline

Konorski J (1967) Integrative activity of the brain. Chicago, IL: Chicago UP.

Krüger O, Shiozawa T, Kreifelts B, Scheffler K, Ethofer T (2015) Three distinct fiber pathways of the bed nucleus of the stria terminalis to the amygdala and prefrontal cortex. Cortex 66:60-68. CrossRef Medline

LeDoux JE (2000) Emotion circuits in the brain. Annu Rev Neurosci 23:155-184. CrossRef Medline

LeDoux JE, Iwata J, Cicchetti P, Reis DJ (1988) Different projections of the central amygdaloid nucleus mediate autonomic and behavioral correlates of conditioned fear. J Neurosci 8:2517-2529. Medline

Leri F, Flores J, Rodaros D, Stewart J (2002) Blockade of stressinduced but not cocaine-induced reinstatement by infusion of noradrenergic antagonists into the bed nucleus of the stria terminalis or the central nucleus of the amygdala. J Neurosci 22:57135718. Medline Medline

Luck CC, Lipp OV (2015) A potential pathway to the relapse of fear? Conditioned negative stimulus evaluation (but not physiological responding) resists instructed extinction. Behav Res Ther 66:1831. CrossRef Medline

Marchand AR, Barbelivien A, Seillier A, Herbeaux K, Sarrieau A, Majchrzak M (2007) Contribution of corticosterone to cued versus contextual fear in rats. Behav Brain Res 183:101-110. CrossRef Medline

Maren S (1998) Overtraining does not mitigate contextual fear conditioning deficits produced by neurotoxic lesions of the basolateral amygdala. J Neurosci 18:3088-3097. Medline

Maren S (2001) Neurobiology of Pavlovian fear conditioning. Annu Rev Neurosci 24:897-931. CrossRef Medline

Maren S (2011) Seeking a spotless mind: extinction, deconsolidation, and erasure of fear memory. Neuron 70:830-845. CrossRef Medline

Maren S (2014) Fear of the unexpected: hippocampus mediates novelty-induced return of extinguished fear in rats. Neurobiol Learn Mem 108:88-95. CrossRef Medline

Maren S, Phan KL, Liberzon I (2013) The contextual brain: implications for fear conditioning, extinction and psychopathology. Nat Rev Neurosci 14:417-428. CrossRef Medline

McElligott ZA, Fox ME, Walsh PL, Urban DJ, Ferrel MS, Roth BL, Wightman RM (2013) Noradrenergic synaptic function in the bed nucleus of the stria terminalis varies in animal models of anxiety and addiction. Neuropsychopharmacology 38:1665-1673. CrossRef Medline

Milad MR, Rauch SL, Pitman RK, Quirk GJ (2006) Fear extinction in rats: implications for human brain imaging and anxiety disorders. Biol Psychol 73:61-71. CrossRef Medline

Milad MR, Rosenbaum BL, Simon NM (2014) Neuroscience of fear extinction: implications for assessment and treatment of fearbased and anxiety related disorders. Behav Res Ther 62:17-23. CrossRef Medline

Morris RW, Furlong TM, Westbrook RF (2005a) Recent exposure to a dangerous context impairs extinction and reinstates lost fear reactions. J Exp Psychol Anim Behav Process 31:40-55. CrossRef Medline

Morris RW, Westbrook RF, Killcross AS (2005b) Reinstatement of extinguished fear by beta-adrenergic arousal elicited by a condi- tioned context. Behav Neurosci 119:1662-1671. CrossRef Medline

Morrison FG, Ressler KJ (2014) From the neurobiology of extinction to improved clinical treatments. Depress Anxiety 31:279-290. CrossRef Medline

Myers KM, Davis M (2002) Behavioral and neural analysis of extinction. Neuron 36:567-584. Medline

Orsini CA, Kim JH, Knapska E, Maren S (2011) Hippocampal and prefrontal projections to the basal amygdala mediate contextual regulation of fear after extinction. J Neurosci 31:17269-17277. CrossRef Medline

Orsini CA, Yan C, Maren S (2013) Ensemble coding of contextdependent fear memory in the amygdala. Front Behav Neurosci 7:199. CrossRef Medline

Pavlov IP (1927) Conditioned reflexes. London: Oxford UP.

Phelix CF, Liposits Z, Paull WK (1992) Serotonin-CRF interaction in the bed nucleus of the stria terminalis: a light microscopic doublelabel immunocytochemical analysis. Brain Res Bull 28:943-948. Medline

Polack CW, Laborda MA, Miller RR (2013) On the differences in degree of renewal produced by the different renewal designs. Behav Processes 99:112-120. CrossRef Medline

Pugh CR, Tremblay D, Fleshner M, Rudy JW (1997) A selective role for corticosterone in contextual-fear conditioning. Behav Neurosci 111:503-511. Medline

Rescorla RA (1988a) Behavioral studies of Pavlovian conditioning. Annu Rev Neurosci 11:329-352. CrossRef Medline

Rescorla RA (1988b) Pavlovian conditioning. It's not what you think it is. Am Psychol 43:151-160. Medline

Rescorla RA, Heth CD (1975) Reinstatement of fear to an extinguished conditioned stimulus. J Exp Psychol Anim Behav Process 1:88-96. Medline

Resstel LB, Alves FH, Reis DG, Crestani CC, Corrêa FM, Guimarães FS (2008) Anxiolytic-like effects induced by acute reversible inactivation of the bed nucleus of the stria terminalis. Neuroscience 154:869-876. CrossRef Medline

Roman CW, Lezak KR, Hartsock MJ, Falls WA, Braas KM, Howard AB, Hammack SE, May V (2014) PAC1 receptor antagonism in the bed nucleus of the stria terminalis (BNST) attenuates the endocrine and behavioral consequences of chronic stress. Psychoneuroendocrinology 47:151-165. CrossRef Medline

Roozendaal B, Hui GK, Hui IR, Berlau DJ, McGaugh JL, Weinberger NM (2006) Basolateral amygdala noradrenergic activity mediates corticosterone-induced enhancement of auditory fear conditioning. Neurobiol Learn Mem 86:249-255. CrossRef Medline

Silberman Y, Winder DG (2013) Emerging role for corticotropin releasing factor signaling in the bed nucleus of the stria terminalis at the intersection of stress and reward. Front Psychiatry 4:42. CrossRef Medline

Sink KS, Davis M, Walker DL (2013) CGRP antagonist infused into the bed nucleus of the stria terminalis impairs the acquisition and expression of context but not discretely cued fear. Learn Mem 20:730-739. CrossRef Medline

Smith RJ, Aston-Jones G (2008) Noradrenergic transmission in the extended amygdala: role in increased drug-seeking and relapse during protracted drug abstinence. Brain Struct Funct 213:43-61. CrossRef Medline

Sparta DR, Jennings JH, Ung RL, Stuber GD (2013) Optogenetic strategies to investigate neural circuitry engaged by stress. Behav Brain Res 255:19-25. CrossRef

Stamatakis AM, Sparta DR, Jennings JH, McElligott ZA, Decot $\mathrm{H}$, Stuber GD (2014) Amygdala and bed nucleus of the stria terminalis circuitry: implications for addiction-related behaviors. Neuropharmacology 76:320-328. CrossRef Medline

Sullivan GM, Apergis J, Bush DE, Johnson LR, Hou M, LeDoux JE (2004) Lesions in the bed nucleus of the stria terminalis disrupt corticosterone and freezing responses elicited by a contextual but not by a specific cue-conditioned fear stimulus. Neuroscience 128:7-14. CrossRef 
Sun N, Cassell MD (1993) Intrinsic GABAergic neurons in the rat central extended amygdala. J Comp Neurol 381-404. CrossRef

Swanson LW (1998) Brain maps: structure of the rat brain. New York, NY: Elsevier.

Swanson LW, Cowan WM (1977) An autoradiographic study of the organization of the efferent connections of the hippocampal formation in the rat. J Comp Neurol 172:49-84. CrossRef Medline

Vansteenwegen D, Hermans D, Vervliet B, Francken G, Beckers T, Baeyens F, Eelen P (2005) Return of fear in a human differential conditioning paradigm caused by a return to the original acquistion context. Behav Res Ther 43:323-336. CrossRef Medline

Vervliet B, Baeyens F, Van den Bergh O, Hermans D (2013a) Extinction, generalization, and return of fear: a critical review of renewal research in humans. Biol Psychol 92:51-58. CrossRef Medline

Vervliet B, Craske MG, Hermans D (2013b) Fear extinction and relapse: state of the art. Annu Rev Clin Psychol 9:215-248. CrossRef Medline

Waddell J, Bouton ME, Falls WA (2008) Central CRF receptor antagonist a-helical CRF9-41 blocks reinstatement of extinguished fear: the role of the bed nucleus of the stria terminalis. Behav Neurosci 22:1061-1069. CrossRef

Waddell J, Morris RW, Bouton ME (2006) Effects of bed nucleus of the stria terminalis lesions on conditioned anxiety: aversive conditioning with long-duration conditional stimuli and reinstatement of extinguished fear. Behav Neurosci 120:324-336. CrossRef Medline

Walker DL, Davis M (1997) Double dissociation between the involvement of the bed nucleus of the stria terminalis and the central nucleus of the amygdala in startle increases produced by conditioned versus unconditioned fear. J Neurosci 17:93759383.

Walker DL, Davis M (2008) Role of the extended amygdala in shortduration versus sustained fear: a tribute to Dr. Lennart Heimer. Brain Struct Funct 213:29-42. CrossRef Medline

Walker DL, Miles LA, Davis M (2009) Selective participation of the bed nucleus of the stria terminalis and CRF in sustained anxietylike versus phasic fear-like responses. Prog Neuropsychopharmacol Biol Psychiatry 33:1291-1308. CrossRef Medline

Walter A, Mai JK, Lanta L, Görcs T (1991) Differential distribution of immunohistochemical markers in the bed nucleus of the stria terminalis in the human brain. J Chem Neuroanat 4:281-298. Medline

Weller KL, Smith DA (1982) Afferent connections to the bed nucleus of the stria terminalis. Brain Res 232:255-270. Medline

Westbrook RF, lordanova M, McNally G, Richardson R, Harris JA (2002) Reinstatement of fear to an extinguished conditioned stimulus: two roles for context. J Exp Psychol Anim Behav Process 28:97-110. Medline

Zelikowsky M, Pham DL, Fanselow MS (2012) Temporal factors control hippocampal contributions to fear renewal after extinction. Hippocampus 22:1096-1106. CrossRef Medline

Zimmerman JM, Maren S (2011) The bed nucleus of the stria terminalis is required for the expression of contextual but not auditory freezing in rats with basolateral amygdala lesions. Neurobiol Learn Mem 95:199-205. CrossRef Medline 